\title{
Amália Kerekes, Melinda Kindl, \& Judit Szabó, eds. Post Festum. Szabadtéri játékok a két világháború között Salzburgban, Szegeden és Pécsett [Post Festum: Outdoor Festivals at Salzburg, Szeged and Pécs during the Interwar Period]. Budapest: Gondolat, 2009. 604
} pp.

\author{
Reviewed by Alexander Vári, Marywood University, Scranton, PA
}

Beginning with the late nineteenth century, Budapest's domination of the Hungarian urban and cultural landscape pushed many provincial cities (unable to match Budapest's rise in political importance and unprecedented demographic, economic, and cultural growth) into relative obscurity. Although as a result of becoming the capital city of a much smaller Hungary, Budapest's administrative importance and demographic weight trebled during the interwar period, two provincial cities - Szeged and Pécs - tried to evade the former's grip on everything that mattered. The outdoor theater and music festivals that were organized in Szeged and Pécs during the 1930s inserted these cities in a central European cultural network at the center of which was neither Vienna nor Budapest (the two biggest cities in the region) but rather Salzburg. Instead of copying Budapest, Szeged and Pécs wanted to carve out their sphere of cultural autonomy by following international models and presenting themselves as Hungarian Salzburgs. The rise of Szeged and Pécs as festival cities is therefore an important episode in Hungary's post-Habsburg history, pointing not just to the rise of cultural decentralization efforts, but to the continuation and relevance of Austro-Hungarian interactions during the interwar period.

While the developments leading to the opening of the Salzburg festival in 1920 as a manifestation of the cultural strength and viability of the post-war Austrian spirit are well known, and have a rich secondary literature (most recently Michael P. Steinberg, Austria as Theater and Ideology: the Meaning of the Salzburg Festival (Ithaca: Cornell University Press, 1990, $2^{\text {nd }}$ edition 2000); Andres Müry, Jedermann darf nich sterben: Geschichte eines Salzburger Kults, 1920-2001 (Salzburg: Pustet, 2001)), much less has been written about the origins, purposes and achievements of the outdoor festivals organized in Szeged and Pécs. Aware of this situation, the editors of Postfestum, an anthology of primary sources covering all three festivals, published recently in Hungary, have set for themselves the goal to rescue the latter from oblivion, and look at the interwar history of the Salzburg, Szeged and Pécs festivals from the perspective of a triangular comparison.

How did Szeged and Pécs relate to Salzburg and each other? Were they able to rise to the status of Hungarian Salzburgs, and even go beyond that to establish their own unique urban identity? Did Salzburg acknowledge their existence? Were their efforts to compete with

$($ (c) $)$ EY

ULIS D-Serk 
Vári, Alexander. “Amália Kerekes, Melinda Kindl, \& Judit Szabó, eds. Post Festum. Szabadtéri játékok a két világháború között Salzburgban, Szegeden és Pécsett [Post Festum: Outdoor Festivals at Salzburg, Szeged and Pécs during the Interwar Period]. Budapest: Gondolat, 2009. 604 pp.” Hungarian Cultural Studies. e-Journal of the American Hungarian Educators Association, Volume 6 (2013): http://ahea.pitt.edu DOI: 10.5195/ahea.2013.136

Budapest successful? And seen from a broader and comparative perspective: what were the goals and ideological priorities of these festivals? Did interwar politics and the international political climate influence their content? What are these outdoor festivals telling us about the connections between festival culture, tourism, and city marketing in Central Europe? To answer such questions, the editors have collected a wide range of journalistic reports from the German and Hungarian press of the 1920s and 1930s, which they have divided - according to their specific content and focus - into three sections: "Programmatic Texts and Debates about Programs," "Criticism and Mutual Reflections" and "Analyses of Plays." In order to contextualize these primary sources, each section opens with an analytically rich introductory essay written by the editors, which is then followed by journalistic reports translated from German as well as rendered in the original Hungarian language, covering the festival events at Salzburg, Szeged and Pécs. The richness of available sources dealing with interwar festival culture in Austria and Hungary is well documented by the fact that in addition to the almost six hundred pages of text, the editors had to create a separate online site at http://germanistik.elte.hu/tudomanykepek/ to provide interested readers with access to longer reports that they were unable to include within the covers of the volume.

The opinions of the founders of the Salzburg festival, most notably among whom were Max Reinhardt and Hugo von Hofmannsthal, are well represented in the selection of programmatic texts that they wrote prior to the opening of the festival, and especially during the 1920s. While in a programmatic text written by Max Reinhardt in 1917, the emphasis fell on the need for a revitalization of German culture through open air theater performances, the promotion of Austrian talent, and the positioning of Salzburg as a tourist destination, in a piece written two years later, Hofmannsthal highlighted the centrality of the eighteenth century cosmopolitan baroque as an expression of the southern German, Austro-Bavarian spirit. Once the idea of the festival was embraced by the local Catholic archbishop, who lent the Salzburg Cathedral's premises for the organization of the event, Jedermann [Everyman], a late fifteenth-century English mystery play adapted for the stage by Hofmannstahl, became a key component of the festival's offerings. The annual representations of Jedermann attracted to Salzburg a rich international clientele, whose presence in the city became a noticeable phenomenon from the mid-1920s onwards. Therefore other programmatic statements uttered by Hofmannsthal and Reinhardt during the late 1920s and mid-1930s recorded the transition from a festival program initially centered on Jedermann to a much richer set of offerings which included the periodic interpretation of musical works by Mozart and Beethoven, the staging of Goethe's Faust, the interpretation of operatic works by Mozart, Gluck, Wagner, Verdi, Puccini and Richard Strauss, as well as a medley of other symphonic works and, though to a lesser extent, the screening of films.

By contrast to Salzburg, the Szeged festival, which opened in 1931, originated in a less straightforward set of developments. Its first initiator was Ferenc Hont, who upon his return from Paris during the mid-1920s (where he studied with Firmin Gémier, the initiator of the French popular theater movement and the director of the International Theater Alliance), wanted to involve local youth in the staging of outdoor theatrical plays. However, once more members of the local intellectual elite became interested in the project, Hont's initiative was connected to the need to raise the overall importance of Szeged within the new (and since 1920 territorially much reduced) Hungarian national landscape. With the relocation, after the Trianon Treaty, of 
Vári, Alexander. “Amália Kerekes, Melinda Kindl, \& Judit Szabó, eds. Post Festum. Szabadtéri játékok a két világháború között Salzburgban, Szegeden és Pécsett [Post Festum: Outdoor Festivals at Salzburg, Szeged and Pécs during the Interwar Period]. Budapest: Gondolat, 2009. 604 pp.” Hungarian Cultural Studies. e-Journal of the American Hungarian Educators Association, Volume 6 (2013): http://ahea.pitt.edu DOI: 10.5195/ahea.2013.136

the formerly Kolozsvár (today Cluj)-based Ferenc József University to Szeged and the concentration of a large group of intellectuals in the city, Szeged was seen by many as acquiring the role of a second cultural center in Hungary, similar to that occupied by Munich and Moscow prior to the war in Imperial Germany and Russia, respectively. The embrace of the local plans for cultural development and decentralization by Kuno Klebelsberg (Hungary's Minister of Religion and Public Education between 1922-1931 and representative of the Szeged electoral district in the Hungarian Parliament from 1926 to 1932) was decisive in enabling the summer festival to open its doors in 1931 on the Dome Square, a four-cornered enclosed space created by the recently built university buildings and the city's imposing neo-Romanic cathedral.

The festival, however, operated with governmental support only during its first year, its organization being taken over in subsequent years by the municipality and the editor of a local daily, the Délmagyarország. Among the goals embraced by the festival organizers with varying emphases between 1931 and 1939 were the following: the promotion of Szeged as a Hungarian Salzburg, as a vessel collecting the cultural energies of the Great Hungarian Plain (Alföld) and as a proof of Hungarians' cultural superiority (kultúrfölény) over their eastern and southern neighbors; the education of the masses through the redemptive power of art; and the international marketing of Hungarian theater and literature. They also wanted to attract Hungarians from the neighboring post-Trianon countries as well as a Western tourist clientele, the arrival of the latter being seen as contributing to Szeged's aim to become a European cultural center. Some of these divergent goals were also reflected in changes in the festival program, which started in 1931 with the staging of Géza Voinovich's Magyar Passió (Hungarian Mystery) as a centerpiece in the program, that was replaced in subsequent years by the theatrical adaptation of Imre Madách's $A z$ Ember tragédiája (The Tragedy of Man), with the organizers adding other Hungarian plays and even several representations of Verdi, Puccini and Mascagni operas in the late 1930s.

By comparison to Salzburg, and even Szeged, the outdoor festival that Pécs hosted intermittently between 1931 and 1938 was of a much lesser scale and importance. The inclusion by the volume's editors of a separate section of texts discussing its aims, however, is an important contribution to the history of the connections between urban development, urban selfimage and city marketing during the interwar period, since it highlights the fierce inter-city competition within Hungary regarding the organization of summer festivals, which by the 1930s became so popular in the country that they were organized not just in Pécs and Szeged, but in Sopron and Kecskemét as well, with Budapest also joining in with the building of the Margitszigeti Szabadtéri Színpad (The Outdoor Stage on Margaret Island) in 1938. However, its copycat status and the program's almost exclusive focus on mystery plays and symphonic music were also elements which made the Pécs festival less prominent in the long run.

The middle sections of the book provide insights into the interactions between Salzburg, Szeged and Pécs. It is here that the reader expects important revelations. Were the Hungarian outdoor festivals able to challenge Salzburg's leading position and carve out a niche for themselves within the international summer festival market? The answer, however, is rather negative. While many Hungarian actors, such as Lili Darvas, Mária Németh and Attila Hörbiger, played main roles in Jedermann, and on occasion the interpretation of symphonic works by Ferenc Erkel, Ernő Dohnányi, Jenő Hubay, Zoltán Kodály and Béla Bartók contributed to the Salzburg festival's fame, this wasn't reciprocated in the case of Szeged and Pécs where (in spite of a state visit made to Szeged by Austrian Chancellor Kurt Schuschnigg in 1934) neither 
Vári, Alexander. “Amália Kerekes, Melinda Kindl, \& Judit Szabó, eds. Post Festum. Szabadtéri játékok a két világháború között Salzburgban, Szegeden és Pécsett [Post Festum: Outdoor Festivals at Salzburg, Szeged and Pécs during the Interwar Period]. Budapest: Gondolat, 2009. 604 pp.” Hungarian Cultural Studies. e-Journal of the American Hungarian Educators Association, Volume 6 (2013): http://ahea.pitt.edu DOI: 10.5195/ahea.2013.136

Austrian actors nor works appeared on stage. As another example of the lack of mutual reciprocity, both Szeged and Pécs claimed to be Hungarian Salzburgs, without interacting at the level of actors and directors with each other. The relationship between these festivals was therefore rather a discursively imagined one (at the level of journalistic comparisons made in the Hungarian press but rarely in the Austrian one), with Salzburg competing rather against the summer festivals staged at Bayreuth, Munich and Oberammergau, than with those in Szeged or Pécs, which mostly fell off the radar of its organizers. A partial exception to this ignorance could have been Max Reinhardt himself, who in 1931 was invited to take over the directorship of the Szeged festival (but declined), and who - because of erroneous references to his birthplace as being located in territories belonging to the old Hungarian Kingdom - was often depicted as a Hungarian in the Hungarian press (although not without occasional anti-Semitic references to his Jewish origin).

Regarding the domestic and international perception of Salzburg during the interwar period, the German and Hungarian texts selected by the editors emphasize the role of Max Reinhardt and the importance of Jedermann as a staple offering that through its repetition every year ensured the tremendous success of the festival. While many praised Reinhardt's energy and artistic achievements as a festival director and organizer, others such as Karl Kraus (an important maverick in the Austrian cultural landscape) or contributors to the Austrian social-democratic press depicted the festival as a fair-like event that was symptomatic of the commercialization and debasement of the postwar level of Austrian culture, while still others saw Salzburg's success as being based on the spectacularization of the everyday and the exploitation of the gullibility of rich tourists from Britain, the US and France, who were always in search of entertainment and the thrill of the new.

While Reinhardt was a towering figure at Salzburg, no similar personality emerged within the context of the Szeged and Pécs festivals. Therefore, instead of celebrating the achievements or berating the misgivings of a director, these festivals were seen rather as enabling the coming of age of these cities. This was especially the case of Szeged, for which the festival represented a third stage in the city's urban becoming, which started with its modern rebuilding after the big flood of 1879 and continued with the city's rise in administrative and academic importance after WWI. However, as its competitors in Pécs pointed out, while the Szeged festival represented another turning point in the city's modern history, the appeal and relevance of the festival was weakened by the fact that it was organized in a city that was much less ancient than Pécs (with no historical monuments that could compete with the latter) as well as because most of the artists who played on the Szeged stage weren't locals but came each summer from Budapest. By contrast, Pécs was proud of the fact that its festival was mostly the result of local efforts, although its organizers admitted that Szeged with its folk (népi) artifacts, fish soup (halászlé) and paprika, offered much more in terms of local color and food to its visitors. However, a commonality that both Szeged and Pécs shared was that - in order to overcome their complex of inferiority vis-à-vis Salzburg and Budapest - both saw themselves as the last bastions of western culture in the East.

The last section of the book offers a rich selection of impressionistic commentaries on the atmosphere and public, as well as theatrical and musical criticism of the most important works that were interpreted on the stages of these three festivals. However, to make the selection more focused, the editors have included only texts that discuss the 1926 interpretation of Jedermann at 
Vári, Alexander. “Amália Kerekes, Melinda Kindl, \& Judit Szabó, eds. Post Festum. Szabadtéri játékok a két világháború között Salzburgban, Szegeden és Pécsett [Post Festum: Outdoor Festivals at Salzburg, Szeged and Pécs during the Interwar Period]. Budapest: Gondolat, 2009. 604 pp.” Hungarian Cultural Studies. e-Journal of the American Hungarian Educators Association, Volume 6 (2013): http://ahea.pitt.edu DOI: 10.5195/ahea.2013.136

Salzburg, the 1934 staging of The Tragedy of Man at Szeged, and the 1936 representation of György Ujházy’s Missa Sollemnis (a mystery play based on music by Ferenc Liszt) at Pécs.

The 1926 season of Jedermann was staged with a cast which included Alexander Moissi, Dagny Servaes, Lili Darvas, Luis Rainer and Max Pallenberg. Some of these actors also appeared in Puccini's Turandot, likewise directed by Reinhardt, and which was included that year in the Salzburg program. Although Moissi's performance in Jedermann's role would become legendary, the texts selected by the editors focus more on the cosmopolitan feel of the festival, the star-like status of Reinhardt, and the disjunction between the entertainment-eager audience frequenting the festival and the spiritual meaning of the mystery play. In addition, press reports also highlight the popularity of Jedermann in Hungary, as it was staged several times with a Hungarian cast in Budapest during that same summer. In the case of The Tragedy of Man, staged in 1934 in Szeged under the directorship of Baron Miklós Bánffy, however, the reports emphasize the technological novelties (the projection of images serving as stage sets on the façade of the cathedral, the use of megaphone to communicate with the actors during rehearsals, etc.), the skillful acting of Gyula Csortos, Oszkár Beregi and Anna Tökés, and - by contrast to its earlier theatrical representations - the enhanced potentialities of Madách's work in the open-air arena. By contrast to these, the reports covering the representation two years later of Ujházy's Missa Sollemnis at Pécs, in spite of some rather far-flung speculations about this southern Hungarian city becoming the Salzburg of the East (with their repetitive emphasis on the connection between this work and the commemoration of two hundred and fifty years since the city's liberation from the Ottoman yoke, the use of an extremely large stage and almost one thousand musicians and non-professional actors, and the participation of the whole city in assuring the representation's success), highlight rather the intensely local and provincial character of the event.

The volume as a whole is also revealing in what the selected texts leave out: discussion of modern plays and of avant-garde literary and artistic works, which were definitely not in the focus of these festivals. The work of modernity can be rather glimpsed in their case through their strong interest in the spectacular, city marketing, and in their fascination with open spaces and the assembling of crowds; features that they shared with the authoritarian and totalitarian ideologies (communism, fascism and Nazism) emerging in Europe during those decades. However, they were far from overlapping with these ideologies, being rather expressions of conservatism, nationalism, and a Christian and neo-baroque spirit which permeated (with the notable exception of social-democratic Vienna) the life of both Hungarian and Austrian society during the interwar period.

Although they did not replace Salzburg as the leading festival center in Central Europe, Szeged and Pécs were able to create through their festivals a more distinct urban profile for themselves within Hungary. The Christian and neo-baroque spirit which they shared with Salzburg points not just at the survival and strong embrace of the Catholic culture associated with the eighteenth-century Habsburg dynasty in post-WWI Hungary but also at its theatrical enactment in Szeged and Pécs. At the same time, the placing of Madách's The Tragedy of Man at the center of the Szeged festival's program represented a turn away from medieval morality plays toward a celebration of Hungarian cultural achievements. Moreover, the plot of The Tragedy of Man, centered on an excursus through the great eras of human history (stretching from Ancient Egypt, Greece, and Rome to the age of the Renaissance, and that of the French and 
Vári, Alexander. “Amália Kerekes, Melinda Kindl, \& Judit Szabó, eds. Post Festum. Szabadtéri játékok a két világháború között Salzburgban, Szegeden és Pécsett [Post Festum: Outdoor Festivals at Salzburg, Szeged and Pécs during the Interwar Period]. Budapest: Gondolat, 2009. 604 pp.” Hungarian Cultural Studies. e-Journal of the American Hungarian Educators Association, Volume 6 (2013): http://ahea.pitt.edu DOI: 10.5195/ahea.2013.136

the industrial revolutions), provided Szeged with a touch of universality that endorsed its selfrepresentation as a European cultural center. However, revisionist Hungarian politics also weighed heavily in the balance when Szeged and Pécs imagined themselves as European civilizational outposts and cultural models for their (as they put it) less civilized eastern and southern neighbors. Lastly but equally important, these festivals aimed to turn themselves into new tourist destinations, counting on the fact that the arrival of large numbers of visitors will enhance both their domestic and international visibility.

With its deep probing into interwar discourses about Salzburg, Szeged and Pécs, the Kerekes et al. volume (which also distinguishes itself through its rich illustrations, solid bibliography and elegant presentation) represents an important scholarly resource that will be hard not to be taken into account by scholars interested in the early history of summer festivals in Central Europe. Nevertheless, these texts should also be read in conjunction with a number of interwar histories of the Salzburg and Szeged festivals (e.g.: Erwin Kerber, Ewiges Theater: Salzburg und seine Festspiele (München: Piper, 1935); Döme Lugosi, A Szegedi Szabadtéri Játékok története, 1931-1937 (Budapest: A Színpad, 1938); József Pásztor, A Szegedi Szabadtéri Játékok története. Három Év. Monográfia (Szeged: Városi Nyomda és Könyvkiadó, 1938); Hugo von Hoffmansthal, Festspiele in Salzburg (Wien: Bermann-Fischer, 1938)). Looking at early histories is especially important for the understanding of these festivals (which, with the exception of Pécs, are still in operation today), since their authors recorded them as phenomena in the making before their life was cut short by the 1938 annexation of Austria by Nazi Germany (which led to the fleeing of Reinhardt and many actors, composers and directors in conjunction with the Nazification of the Salzburg festival) and the start of WWII, which prompted the closing of the Szeged and Pécs festivals. Finally, although the translation of pertinent German texts into Hungarian provides a great service to non-German speakers and to students of this topic in Hungary, translation of the Hungarian texts into German (and perhaps of the whole volume into English) would have made this selection more relevant not just for a German speaking audience, but for a linguistically much broader readership as well. 